\title{
Characterization of Sarocladium oryzae and its reduction potential of rice leaf blast ${ }^{1}$
}

\author{
Rafaela Araújo Guimarães², Valácia Lemes da Silva Lobo ${ }^{3}$, \\ Márcio Vinícius Carvalho Barros Côrtes ${ }^{3}$, Marta Cristina Corsi de Filippi ${ }^{3}$, Anne Sitarama Prabhu ${ }^{3}$
}

\begin{abstract}
The integrated management of rice leaf blast (Magnaporthe oryzae) is carried out mainly with the adoption of chemical control. However, the search for alternative practices has grown in recent years. Thus, the variability of 28 Sarocladium oryzae isolates was evaluated for the cerulenin production, as well as its potential for reducing the severity of rice leaf blast, quantifying the activity of enzymes linked to the plant defense mechanisms. More than $55 \%$ of the $S$. oryzae isolates were antagonistic to the pathogens $M$. oryzae, Cochliobolus miyabeanus, Thanatephorus cucumeris and Monographella albescens, and $60 \%$ of the isolates produced cerulenin at detectable levels. Both BRM $6461\left(296.0 \mu \mathrm{g} \mathrm{mL}^{-1}\right)$ and BRM 6493 (undetectable cerulenin) inhibited the formation of M. oryzae appressoria in $89.5 \%$ and $85 \%$, respectively. The BRM 6461 isolate, applied as conidial suspension and filtered, reduced the severity of rice leaf blast in $68.8 \%$ and $75.5 \%$, respectively. The enzymatic activity in the presence of $M$. oryzae was higher for lipoxygenase at $5 \mathrm{~h}$ (filtered) and at $24 \mathrm{~h}$ and $72 \mathrm{~h}$ (conidial suspension) after the pathogen inoculation. For phenylalanine ammonia lyase, the highest expression was at $5 \mathrm{~h}$ (filtered) and $72 \mathrm{~h}$ (conidial suspension). The enzymes chitinase, $\beta-1,3-$ glucanase and peroxidase and the salicylic acid phytohormone presented no differences, in relation to the controls (water and M. oryzae). The filtered from the BRM 6461 isolate, basically constituted by cerulenin, reduced the severity of rice leaf blast and possibly activated the defense mechanisms of the rice plants against $M$. oryzae.
\end{abstract}

KEYWORDS: Magnaporthe oryzae; cerulenin; biocontrol; enzyme activity.

\section{INTRODUCTION}

Rice leaf blast, caused by Magnaporthe oryzae [B. Couch (anamorph: Pyricularia oryzae Cavara)] (Klaubauf et al. 2014), is one of the most destructive diseases in rice crops (Fisher et al. 2012) and may

\section{RESUMO}

Caracterização de Sarocladium oryzae e seu potencial na redução de brusone foliar em arroz

O manejo integrado de brusone (Magnaporthe oryzae) em arroz é realizado, principalmente, com a adoção de controle químico. No entanto, a busca por práticas alternativas tem crescido nos últimos anos. Assim, avaliou-se a variabilidade de 28 isolados de Sarocladium oryzae, quanto à produção de cerulenina, e o seu potencial na redução da severidade de brusone foliar em arroz, quantificando-se a atividade de enzimas ligadas ao mecanismo de defesa das plantas. Mais de $55 \%$ dos isolados de $S$. oryzae foram antagônicos aos patógenos M. oryzae, Cochliobolus miyabeanus, Thanatephorus cucumeris e Monographella albescens, e $60 \%$ dos isolados produziram cerulenina em níveis detectáveis. Tanto BRM $6461\left(296,0 \mu \mathrm{g} \mathrm{mL}^{-1}\right)$ quanto BRM 6493 (cerulenina não detectável) inibiram a formação de apressórios de $M$. oryzae em 89,5 \% e $85 \%$, respectivamente. O isolado BRM 6461, aplicado na forma de suspensão de conídios e filtrado, reduziu a severidade da brusone em $68,8 \%$ e 75,5 \%, respectivamente. A atividade enzimática, na presença de $M$. oryzae, foi maior para lipoxigenase após $5 \mathrm{~h}$ (filtrado) e 24 h e 72 h (suspensão de conídios) da inoculação do patógeno. Para fenilalanina-amônia liase, a maior expressão ocorreu após $5 \mathrm{~h}$ (filtrado) e 72 h (suspensão de conídios). As enzimas quitinase, $\beta$-1,3-glucanase e peroxidase e o fitohormônio ácido salicílico não apresentaram diferenças em relação aos controles (água e $M$. oryzae). O filtrado do isolado BRM 6461, constituído basicamente por cerulenina, reduziu a severidade da brusone e, possivelmente, ativou os mecanismos de defesa da planta de arroz contra M. oryzae.

PALAVRAS-CHAVE: Magnaporthe oryzae; cerulenina; biocontrole; atividade enzimática.

cause grain yield losses of up to $100 \%$ (Prabhu et al. 2009) in all producing regions (Chen et al. 2013).

It is controlled using an integrated management system, involving strategies such as chemical control, crop management techniques and resistant cultivars. The application of chemical fungicides is the most

1. Manuscript received in Aug./2016 and accepted for publication in Mar./2017 (http://dx.doi.org/10.1590/1983-40632016v4742738).

2. Universidade Federal de Goiás, Escola de Agronomia, Goiânia, GO, Brazil.E-mail: rafaela_argui@hotmail.com.

3. Empresa Brasileira de Pesquisa Agropecuária (Embrapa Arroz e Feijão), Laboratório de Microbiologia Agrícola, Santo Antônio de Goiás, GO, Brazil.E-mails: valacia.lobo@embrapa.br, marcio.cortes@embrapa.br, cristina.filippi@embrapa.br, prabhu.anne@colaborador.embrapa.br. 
widely used method, however, it has negative impacts on the environment (Meng et al. 2015), besides promoting the resistance of certain pathogen molecules, resulting in the effectiveness loss of some active ingredients (Oliveira et al. 2015). One of the most efficient rice leaf blast control methods is the use of resistant cultivars. However, this resistance is rapidly overcome in the field, due to the high variability and complexity of the disease-causing pathogen (Chen et al. 2013).

Recently, biological control agents have been suggested as an additional management strategy (Nie et al. 2014). These agents can act as direct antagonists, inhibiting the growth and/or development of plant pathogens, or resistance inducers, promoting a resistance to biotic and/or abiotic stresses by activating gene expression and metabolic pathways, thereby triggering defense mechanisms such as systemic acquired resistance and induced systemic resistance (Van Loon et al. 1998, Shoresh et al. 2010).

The systemic acquired resistance is normally triggered by localized infection and provides longterm systemic resistance. It involves the activation of pathogenesis-related genes with antimicrobial activity which encode proteins that use salicylic acid as a signaling molecule (Durrant \& Dong 2004, Pieterse et al. 2009), with salicylic acid levels increasing when the pathogen is detected (Mishina \& Zeier 2007, Tsuda et al. 2008). The induced systemic resistance occurs as a response to root colonization by nonpathogenic agents that can phenotypically induce this type of resistance (Van Loon et al. 1998, Pieterse et al. 2009), and requires additional signaling components not dependent on salicylic acid (Shoresh et al. 2010). Both systemic acquired resistance and induced systemic resistance have been employed successfully in rice, using different biotic and abiotic resistance inducers (Smith \& Métraux 1991, Manandhar et al. 1998, Tsukamoto et al. 1999, Ashizawa et al. 2005, Filippi et al. 2007 and 2011, Sena et al. 2013).

A number of studies have been conducted in recent years using the rice blast pathosystem and different biocontrol agents, such as rhizobacteria, Epicoccum sp. and Cladosporium sp. (Fillipi et al. 2011, Sena et. al. 2013, Chaibub et al. 2016), which can act as resistance inducers. The Sarocladium oryzae [(Sawada) W. Gams \& D. Hawksw] fungus is the causal agent of sheath rot, however, in rice, this disease only occurs in the stem during the reproductive phase and is not found in leaves.
S. oryzae is also known for its antagonistic potential against other disease-causing fungi in rice, including M. oryzae (Gnanamanickam \& Mew 1991, Sakthivel et al. 2002, Silva et al. 2007). This fungus produces cerulenin as a secondary metabolite, which acts as a potent inhibitor of fatty acid and steroid metabolism (Omura 1976, Hittalmani et al. 2016), exhibiting in vivo and in vitro antagonistic behavior against certain fungal and bacterial rice pathogens (Sakthivel \& Gnanamanickam 1986, Gnanamanickam \& Mew 1991, Padmavathi et al. 1997, Prabhu et al. 2007, Côrtes et al. 2014).

This study aimed at evaluating the variability, in relation to cerulenin production, of $28 \mathrm{~S}$. oryzae isolates, as well as the $S$. oryzae potential to reduce the severity of rice leaf blast, in addition to quantifying the activity of enzymes linked to plant defense mechanisms.

\section{MATERIAL AND METHODS}

The experiments were conducted at the Embrapa Arroz e Feijão, in Santo Antônio de Goiás, Goiás State, Brazil, from 2013 to 2014, using 32 isolates from its collection of multifunctional microorganisms and fungi. A total of $28 S$. oryzae isolates, as well as one isolate of the pathogens Magnaporthe oryzae, Cochliobolus miyabeanus, Thanatephorus cucumeris and Monographella albescens, were used.

The antagonistic potential of the $S$. oryzae isolates against $M$. oryzae, C. miyabeanus, $T$. cucumeris and $M$. albescens fungi was assessed using the paired cultures method (Romeiro 2007). Mycelial discs with $5 \mathrm{~mm}$ in diameter were placed $45 \mathrm{~mm}$ apart on opposite sides of a Petri dish containing potato-dextrose-agar growth medium, with one disc consisting of the pathogen under study and the other a $S$. oryzae isolate. In the control treatment, pathogens were grown separately with a mycelial disc in the center of the dish. The inhibition zone was measured as soon as the control reached full growth. Analyses were carried out using a completely randomized design and the experiment was conducted in triplicate and means compared by the Scott-Knott test ( $p \leq 0.05)$, using the SASM-Agri software (Canteri et al. 2001). All pathogens were used in the asexual phase.

For the cerulenin quantification, the $S$. oryzae isolates were grown separately on potato-dextroseagar medium and incubated at $25^{\circ} \mathrm{C}$. After 10 days, a 
$5 \mathrm{~mm}$-wide mycelial disc was transferred to $100 \mathrm{~mL}$ of a liquid medium (Omura 1976) containing 1.0\% of glucose, $3.0 \%$ of glycerol, $0.5 \%$ of peptone and $0.2 \%$ of sodium chloride, and incubated for 8 days, at $150 \mathrm{rpm}$ and $25{ }^{\circ} \mathrm{C}$, to obtain the crude extract. The extract was then submitted to a vacuum with chloroform at a ratio of $1: 1(\mathrm{v} / \mathrm{v})$, crystallized and diluted in $2 \mathrm{~mL}$ of ethanol, resulting in the concentrated extract or cerulenin (Côrtes et al. 2014), which was quantified by high performance liquid chromatography using a Perkin Elmer Flexar ${ }^{\mathrm{TM}}$ system (Bills et al. 2004), in a reversed-phase C18 column measuring $150 \mathrm{~mm}$ x $4.6 \mathrm{~mm}$ x $5 \mu \mathrm{m}$, with a fixed temperature of $40{ }^{\circ} \mathrm{C}$, where the mobile phase $\mathrm{B}$ (acetonitrile) was diluted in water (A). A commercial cerulenin standard (Sigma) was used, obtaining a standard curve from concentrations of $0.00125-2 \mu \mathrm{g} \mu \mathrm{L}^{-1}$. Readings were performed using the Chromera software (Perkin Elmer) at a wavelength of $210 \mathrm{~nm}$. Analyses were carried out using a completely randomized design in triplicate and means compared by the Scott-Knott test ( $\leq 0.05)$, using the SASM-Agri software (Canteri et al. 2001).

The filtrates of the S. oryzae BRM 6461 and BRM 6493 isolates were assessed in terms of their effect on conidial germination and appressorium formation in $M$. oryzae. The filtrate was obtained based on the methodology proposed by Côrtes et al. (2014) and the M. oryzae conidial suspension according to Filippi \& Prabhu (2001), and adjusted for a concentration of $1 \times 10^{4}$ conidia $\mathrm{mL}^{-1}$. The suspensions were placed on a glass slide and covered with artificial superhydrophobic surface material. The treatments were: $10 \mu \mathrm{L}$ of BRM $6461+10 \mu \mathrm{L}$ of $M$. oryzae conidial suspension; $10 \mu \mathrm{L}$ of BRM $6493+10 \mu \mathrm{L}$ of $M$. oryzae conidial suspension; and $10 \mu \mathrm{L}$ of $M$. oryzae conidial suspension $+10 \mu \mathrm{L}$ of sterile distilled water. The experiment was performed in a completely randomized design at triplicate and analyzed after 1,3, 6, 12 and $20 \mathrm{~h}$ of incubation (room temperature) and the data and means compared by the Tukey test $(\mathrm{p} \leq 0.05)$, using the SASM-Agri software (Canteri et al. 2001). Sixty M. oryzae conidia were observed using an epifluorescence microscope in $0.1 \%$ calcofluor-white stain (Sigma) at $40 \mathrm{X}$ magnification. Conidia were considered germinated on formation of the germ tube and appressoria were deemed formed when there was a globular structure at the base of the germ tube (cell differentiation), responsible for penetrating the host.
In order to assess enzyme activity, a greenhouse experiment was carried out using the 'BRS Primavera' rice cultivar, which is susceptible to rice leaf blast. Seeds were planted in plastic trays $(15 \mathrm{~cm} \times 30 \mathrm{~cm} \times 10 \mathrm{~cm})$ containing $3 \mathrm{~kg}$ of soil fertilized with NPK (5-30-15), as well as the micronutrients zinc sulfate and iron sulfate. The soil used was collected from virgin Savannah and identified as Eutrophic Red Latosol (Embrapa 2013), with the following characteristics: $\mathrm{pH}\left(\mathrm{H}_{2} \mathrm{O}\right)=$ 5.4; clay $=589.0 \mathrm{~g} \mathrm{~kg}^{-1}$; silt $=66.0 \mathrm{~g} \mathrm{~kg}^{-1}$; sand $=$ $144.0 \mathrm{~g} \mathrm{~kg}^{-1} ; \mathrm{K}^{+}=63.0 \mathrm{mg} \mathrm{dm}{ }^{-3} ; \mathrm{P}=4.0 \mathrm{mg} \mathrm{dm}^{-3}$; $\mathrm{Ca}^{+2}=0.4 \mathrm{mg} \mathrm{dm}{ }^{-3} ; \mathrm{Mg}^{+2}=0.2 \mathrm{cmol}_{\mathrm{c}} \mathrm{dm}^{-3} ; \mathrm{Al}^{+3}=$ $0.1 \mathrm{cmol}_{\mathrm{c}} \mathrm{dm}^{-3} ; \mathrm{Si}=3.0 \mathrm{mg} \mathrm{kg}^{-1}$.

Nitrogen in the form of ammonium sulfate $\left[(\mathrm{NH} 4)_{2} \mathrm{SO}_{4}+\mathrm{Fe}\right.$ and Bo] was applied to the topsoil at 14 and 19 days after planting (DAP). The $S$. oryzae BRM 6461 isolate in the form of concentrated filtrate and conidial suspension $\left(3 \times 10^{5}\right.$ conidia $\left.\mathrm{mL}^{-1}\right)$ was sprayed at $48 \mathrm{~h}$ prior to the inoculation with M. oryzae (BRM 31295 isolate), at a concentration of $3 \times 10^{5}$ conidia $\mathrm{mL}^{-1}$, at 21 DAP. The M. oryzae inoculum was obtained as described by Filippi \& Prabhu (2001). A randomized block design was used, with three replications, each consisting of one tray containing around 80 plants, and six treatments: $\mathrm{T} 1=$ control (water); $\mathrm{T} 2=$ spraying with $S$. oryzae filtrate; T3 = spraying with $S$. oryzae conidial suspension; $\mathrm{T} 4=$ spraying with $S$. oryzae filtrate at $48 \mathrm{~h}$ before the inoculation with $M$. oryzae; T5 = spraying with conidial suspension at $48 \mathrm{~h}$ before the inoculation with $M$. oryzae; and T6 = inoculation with $M$. oryzae.

Rice leaf blast severity was assessed in three treatments: plant inoculated with $M$. oryzae (control) and plants sprayed with $S$. oryzae conidial suspension and BRM 6461 filtrate, at $48 \mathrm{~h}$ before the inoculation with $M$. oryzae. Twenty plants per treatment were evaluated by using a grading scale with scores ranging from 0 to 9 (Leung et al. 1988). Four assessments were conducted, being the first at the onset of symptom emergence. The data were used to calculate the area under the disease-progress curve (Campbell \& Madden 1990), and the reduction in disease severity was determined by using the McKinney index (Balardin et al. 1990). Analyses were carried out in a completely randomized design and the data submitted to analysis of variance and means compared by the Tukey test $(\mathrm{p} \leq 0.05)$, using the SASM-Agri software (Canteri et al. 2001). 
The quantification of the enzymatic activity and salicylic acid content in the rice leaves was performed in six treatments (T1, T2, T3, T4, T5 and T6), using 10 to 15 leaves per treatment. The first leaf collection was done prior to the $M$. oryzae inoculation, while the second, third, fourth, fifth and sixth were carried out at 3, 5, 24, 48 and $72 \mathrm{~h}$ after the pathogen inoculation.

The samples were ground with liquid nitrogen and the protein extract obtained using a lysis buffer [(10 Mm of Tris- $\mathrm{HCl} ; 150 \mathrm{mM}$ of $\mathrm{NaCl} ; 2 \mathrm{Mm}$ of EDTA (ethylenediaminetetraacetic acid); $2 \mathrm{Mm}$ of DTT (2-mercaptoethanol); $1 \mathrm{Mm}$ of PMSF (phenylmethylsulfonyl fluoride), Leptin $\left(10 \mathrm{mg} \mathrm{mL}^{-1}\right)$ and aprotinin $\left.\left(10 \mathrm{mg} \mathrm{mL}^{-1}\right)\right]$. Total protein was quantified by the colorimetric method (Bradford 1976) and readings were performed in a spectrophotometer, at a wavelength of $595 \mathrm{~nm}$, using the Gen5 Data Analyses software (Biotek). The standard curve for total proteins with bovine serum albumin was obtained with different concentrations $\left(0-1 \mathrm{mg} \mathrm{mL}^{-1}\right)$.

The activity of chitinase (EC 3.1.1.14) and $\beta$-1,3-glucanase (EC 3.2.1.6) were determined as described by Pan et al. (1991), with modifications, using colloidal chitin and soluble laminarin as substrate, respectively. The reducing sugars resulting from the reactions were quantified using the 3,5-dinitrosalicylic acid method. Readings performed were adjusted to $540 \mathrm{~nm}$, with the Gen5 Data Analyses software. Lipoxygenase (EC 1.13.11.12) activity was assessed using the method described by Axelrod et al. (1981) and readings were performed on a spectrophotometer, at a wavelength of $234 \mathrm{~nm}$. Peroxidase (EC 1.11.1.7) activity was established according to the method proposed by Keesey (1987) and modified by Côrtes et al. (2008), using a spectrophotometer adjusted to a wavelength of $405 \mathrm{~nm}$ and coupled with the WinSpec 2.3 software, in the kinetic mode. Phenylananine ammonia lyase (EC 4.3.1.5) activity was evaluated based on the method described by Alunni et al. (2003), through quantification of the trans-cinnamic acid generated by hydrolysis of the L-phenylalanine and readings on a spectrophotometer adjusted to $290 \mathrm{~nm}$. The results were expressed as specific activity. Salicylic acid was analyzed in accordance with Yalpani et al. (1991) and quantified by high performance liquid chromatography with mobile phase composed of $23 \%$ of methanol and $77 \% 20 \mathrm{mM}$ of acetate buffer $(\mathrm{pH} 5.0)$, in a $\mathrm{C} 18$ column maintained at a fixed temperature of $35^{\circ} \mathrm{C}$. The ultraviolet detector was adjusted to $280 \mathrm{~nm}$ and coupled with the Chromera software (Perkin Elmer). The data were submitted to statistical analysis using the Statistical Package for the Social Sciences software and means compared by the Tukey test $(\mathrm{p} \leq 0.05)$.

\section{RESULTS AND DISCUSSION}

Of the $28 S$. oryzae isolates analyzed, only six exhibited antagonistic activity against at least one of the pathogens studied (Table 1). BRM 6493 was the best antagonist, producing the largest zones of inhibition for the four pathogens tested.

In order to explain the rate of antagonism between the phytopathogens and the S. Oryzae fungus, isolates of the species were submitted to specific cultivation conditions to determine the production capacity of the secondary metabolite cerulenin. This molecule has been described as the main secondary metabolite responsible for the in vivo and in vitro antagonistic action of $S$. oryzae against rice pathogens (Sakthivel \& Gnanamanickam 1986, Gnanamanickam \& Mew 1991, Prabhu et al. 2007, Côrtes et al. 2014). The results of the present study indicated that 11 of the 28 isolates analyzed showed no detectable levels of this metabolite. BRM 6461 stood out from the remaining isolates, achieving a cerulenin production of $296 \mu \mathrm{g} \mathrm{mL}^{-1}$ (Table 2), more than twice as high as the second best ceruleninproducing isolate.

However, a comparison between data for in vitro antagonism and cerulenin production capacity found that isolates such as BRM 6493, which did not exhibit detectable cerulenin levels, were considered superior antagonists to the different pathogens. Thus, it is believed that in vitro antagonism was not only due to cerulenin production by some of the $S$. oryzae isolates, but also secondary metabolites such as helvolic acid, also often related to in vitro antagonism (Tschen \& Wen 1980, Tschen et al. 1997). Another hypothesis is the production of other hitherto disregarded secondary metabolites, which may influence antagonistic behavior between species. Thus, it can be inferred that cerulenin was not the only molecule responsible for antagonistic action against pathogens in the in vitro mycelial development of S. oryzae. This information raises the possibility that molecules such as helvolic acid and others not described here, likely produced on a smaller scale, 
Table 1. Inhibition of the mycelial growth of phytopathogenic rice fungi by Sarocladium oryzae.

\begin{tabular}{|c|c|c|c|c|}
\hline \multirow{2}{*}{$\begin{array}{c}\text { Sarocladium } \\
\text { oryzae }\end{array}$} & $\begin{array}{c}\text { Cochliobolus } \\
\text { miyabeanus }\end{array}$ & $\begin{array}{c}\text { Magnaporthe } \\
\text { oryzae }\end{array}$ & $\begin{array}{c}\text { Monographella } \\
\text { albescens }\end{array}$ & $\begin{array}{c}\text { Thanatephorus } \\
\text { cucumeris }\end{array}$ \\
\hline & \multicolumn{4}{|c|}{ Inhibition zone $(\mathrm{mm}) *$} \\
\hline BRM 6458 & $7.16 \mathrm{c}$ & $3.55 \mathrm{~d}$ & $7.20 \mathrm{~b}$ & $0.28 \mathrm{c}$ \\
\hline BRM 6459 & $0.76 \mathrm{~d}$ & $0.25 \mathrm{e}$ & $0.66 \mathrm{c}$ & $0.00 \mathrm{c}$ \\
\hline BRM 6461 & $9.27 \mathrm{~b}$ & $3.87 \mathrm{~d}$ & $2.31 \mathrm{c}$ & $2.29 \mathrm{c}$ \\
\hline BRM 6463 & $7.18 \mathrm{c}$ & $9.10 \mathrm{~b}$ & $8.03 \mathrm{a}$ & $1.75 \mathrm{c}$ \\
\hline BRM 6464 & $0.64 \mathrm{~d}$ & $3.61 \mathrm{~d}$ & $0.52 \mathrm{c}$ & $0.00 \mathrm{c}$ \\
\hline BRM 6465 & $0.63 \mathrm{~d}$ & $8.62 \mathrm{~b}$ & $3.79 \mathrm{c}$ & $0.00 \mathrm{c}$ \\
\hline BRM 6466 & $8.25 \mathrm{~b}$ & $0.31 \mathrm{e}$ & $1.50 \mathrm{c}$ & $0.00 \mathrm{c}$ \\
\hline BRM 6467 & $11.92 \mathrm{a}$ & $3.47 \mathrm{~d}$ & $3.98 \mathrm{~b}$ & $0.64 \mathrm{c}$ \\
\hline BRM 6469 & $9.76 \mathrm{~b}$ & $9.60 \mathrm{~b}$ & $9.12 \mathrm{a}$ & $0.00 \mathrm{c}$ \\
\hline BRM 6470 & $0.43 \mathrm{~d}$ & $0.12 \mathrm{e}$ & $0.63 \mathrm{c}$ & $0.00 \mathrm{c}$ \\
\hline BRM 6472 & $10.77 \mathrm{a}$ & $6.61 \mathrm{c}$ & $8.07 \mathrm{a}$ & $5.47 \mathrm{~b}$ \\
\hline BRM 6473 & $12.34 \mathrm{a}$ & $4.76 \mathrm{~d}$ & $7.58 \mathrm{~b}$ & $5.37 \mathrm{~b}$ \\
\hline BRM 6475 & $11.96 \mathrm{a}$ & $4.20 \mathrm{~d}$ & $2.70 \mathrm{c}$ & $0.00 \mathrm{c}$ \\
\hline BRM 6475 & $13.01 \mathrm{a}$ & $7.34 \mathrm{c}$ & $8.50 \mathrm{a}$ & $5.45 \mathrm{~b}$ \\
\hline BRM 6476 & $9.01 \mathrm{~b}$ & $0.87 \mathrm{e}$ & $5.63 \mathrm{~b}$ & $0.47 \mathrm{c}$ \\
\hline BRM 6477 & $0.87 \mathrm{~d}$ & $0.32 \mathrm{e}$ & $0.43 \mathrm{c}$ & $0.00 \mathrm{c}$ \\
\hline BRM 6481 & $7.51 \mathrm{c}$ & $1.13 \mathrm{e}$ & $9.00 \mathrm{a}$ & $1.25 \mathrm{c}$ \\
\hline BRM 6485 & $0.53 \mathrm{~d}$ & $0.95 \mathrm{e}$ & $2.50 \mathrm{c}$ & $0.00 \mathrm{c}$ \\
\hline BRM 6486 & $8.98 \mathrm{~b}$ & $9.30 \mathrm{~b}$ & $9.02 \mathrm{a}$ & $0.46 \mathrm{c}$ \\
\hline BRM 6488 & $11.91 \mathrm{a}$ & $10.09 \mathrm{~b}$ & $6.19 \mathrm{~b}$ & $5.67 \mathrm{~b}$ \\
\hline BRM 6489 & $8.28 \mathrm{~b}$ & $7.87 \mathrm{c}$ & $8.58 \mathrm{a}$ & $2.87 \mathrm{c}$ \\
\hline BRM 6491 & $13.55 \mathrm{a}$ & $3.72 \mathrm{~d}$ & $5.09 \mathrm{~b}$ & $1.00 \mathrm{c}$ \\
\hline BRM 6493 & $13.76 \mathrm{a}$ & $13.28 \mathrm{a}$ & $10.29 \mathrm{a}$ & $8.69 \mathrm{a}$ \\
\hline BRM 6495 & $0.48 \mathrm{~d}$ & $0.87 \mathrm{e}$ & $0.95 \mathrm{c}$ & $0.00 \mathrm{c}$ \\
\hline BRM 6497 & $5.58 \mathrm{c}$ & $1.72 \mathrm{e}$ & $1.62 \mathrm{c}$ & $1.15 \mathrm{c}$ \\
\hline So A & $9.37 \mathrm{~b}$ & $6.07 \mathrm{c}$ & $10.29 \mathrm{a}$ & $0.54 \mathrm{c}$ \\
\hline $53 \mathrm{~B}$ & $8.10 \mathrm{~b}$ & $2.33 \mathrm{~d}$ & $6.58 \mathrm{~b}$ & $0.35 \mathrm{c}$ \\
\hline Am 11 & $1.27 \mathrm{~d}$ & $0.13 \mathrm{e}$ & $1.04 \mathrm{c}$ & $0.00 \mathrm{c}$ \\
\hline Control & $0.00 \mathrm{~d}$ & $0.00 \mathrm{e}$ & $0.00 \mathrm{c}$ & $0.00 \mathrm{c}$ \\
\hline
\end{tabular}

* Means followed by the same letter do not differ statistically according to the Skott-Knott test $(\mathrm{p} \leq 0.05)$.

are acting as inhibitors of $M$. oryzae cell growth, in vitro, under the conditions described.

In addition to the antagonistic effect on mycelial growth, the inhibition of the conidial germination and appressorium formation of phytopathogens are of significant interest when the aim is to select biocontrol agents or molecules, particularly in terms of rice leaf blast management. In this respect, the $S$. oryzae BRM 6461 and BRM 6493 isolates were tested against M. oryzae conidia, exhibiting a delay in germ tube emergence in the first hour and $89.5 \%$ and $85 \%$ formation of M. oryzae appressoria, respectively (Table 3, Figure 1). The results shown by BRM 6461 were similar to those found by Côrtes et al. (2014) and Ohtake et al. (1999), who associated the reduced $M$. oryzae appressorium formation with increased cerulenin levels.

It is important to underscore that the metabolite cerulenin acts in the inhibition of lipid synthesis, one of the main components needed for the germ tube and appressorium formation in M. oryzae (Ebbole 2007). However, the BRM 6493 isolate displayed a marked inhibitory effect on appressorium formation: it did not produce cerulenin. The method used to produce the filtrate analyzed favors the cerulenin production and therefore hampers the helvolic acid production, which is generated in insignificant quantities (Omura 1976). This strengthens the hypothesis that secondary metabolites other than cerulenin and helvolic acid are produced and may be responsible for the inhibitory effect.

Based on the previous results, the $S$. oryzae BRM 6461 isolate was selected to assess the action of $S$. oryzae in reducing the severity of rice leaf blast. The experiment demonstrated that the concentrated filtrate or conidial suspension applied at $48 \mathrm{~h}$ before the inoculation with $M$. oryzae promoted reductions 
of up to $75.5 \%$ and $68.8 \%$ in disease severity, respectively. Comparatively, the treatment with filtrate decreased rice leaf blast more effectively, in relation to the treatment with the $S$. oryzae conidial suspension (Figure 2). However, although this difference is statistically significant, it is not enough to be explained by the difference in the cerulenin concentration potentially present on the leaf surface at the moment of interaction with the pathogen. A far higher effect on disease reduction was expected in

Table 2. Cerulenin production by Sarocladium oryzae isolates.

\begin{tabular}{lc}
\hline Sarocladium oryzae isolate & Amount of cerulenin $(\mu \mathrm{g} \mathrm{mL}-1)$ \\
\hline BRM 6461 & $296.0 \mathrm{a}$ \\
BRM 6469 & $122.3 \mathrm{~b}$ \\
BRM 6475 & $64.5 \mathrm{c}$ \\
BRM 6473 & $55.5 \mathrm{c}$ \\
BRM 6472 & $53.8 \mathrm{c}$ \\
BRM 6477 & $52.0 \mathrm{c}$ \\
BRM 6476 & $48.9 \mathrm{c}$ \\
BRM 6489 & $46.1 \mathrm{c}$ \\
So A & $38.3 \mathrm{c}$ \\
BRM 6491 & $27.8 \mathrm{~d}$ \\
BRM 6488 & $26.5 \mathrm{~d}$ \\
BRM 6459 & $20.0 \mathrm{~d}$ \\
BRM 6463 & $14.6 \mathrm{~d}$ \\
BRM 6481 & $13.2 \mathrm{~d}$ \\
BRM 6465 & $7.5 \mathrm{e}$ \\
BRM 6475 & $5.2 \mathrm{e}$ \\
BRM 6497 & $5.2 \mathrm{e}$ \\
BRM 6458 & nd \\
BRM 6464 & nd \\
BRM 6466 & nd \\
BRM 6467 & nd \\
BRM 6470 & nd \\
BRM 6485 & nd \\
BRM 6486 & nd \\
BRM 6493 & nd \\
BRM 6495 & nd \\
53B & nd \\
Am 11 & nd \\
(1) &
\end{tabular}

* Means followed by the same letter do not differ statistically according to the Skott-Knott test $(\mathrm{p} \leq 0.05)$. nd: non-detectable levels. the presence of the concentrated filtrate, containing high cerulenin levels, than the treatment consisting of $S$. oryzae conidia isolated, together with their locally produced metabolites, possibly including cerulenin.

In this respect, the hypothesis tested was whether both the $S$. oryzae filtrate and conidia, in addition to exhibiting antagonistic action against the pathogen, might be acting indirectly on the defense system of the rice plants through a process called induced resistance, promoting the expression of pathogenesis-related proteins. The pathogenesisrelated protein expression was assessed by measuring the activity of five representative enzymes, in addition to the phytohormone salicylic acid. There are reports of increased expression of these enzymes and salicylic acid in potentially beneficial interactions among $M$. oryzae, rice and other microorganisms, confirming the induced resistance phenomenon and helping to suppress rice leaf blast (Filippi et al. 2014, Chaibub et al. 2016).

When applied in the absence of M. oryzae, the $S$. oryzae filtrate increased the chitinase activity $(48 \mathrm{~h}$ after application), $\beta$-1,3-glucanase ( $5 \mathrm{~h}$ and $48 \mathrm{~h}$ after application) and peroxidase ( $48 \mathrm{~h}$ after application) in rice leaves, while for the conidial suspension the highest values were observed for $\beta$-1,3-glucanase ( $5 \mathrm{~h}, 24 \mathrm{~h}$ and $48 \mathrm{~h}$ after application) and peroxidase ( $5 \mathrm{~h}$ and $48 \mathrm{~h}$ after application). With respect to the enzyme activity in rice leaves sprayed with $S$. oryzae at $48 \mathrm{~h}$ before the inoculation with $M$. oryzae, the highest activity was recorded for lipoxygenase at $5 \mathrm{~h}$ when sprayed with the filtrate and at $24 \mathrm{~h}$ and $72 \mathrm{~h}$ with the conidial suspension. Phenylalanine ammonia lyase showed activity at $5 \mathrm{~h}$ after the treatment with the filtrate and after $72 \mathrm{~h}$ with the conidial suspension. No differences were found in the expression of chitinase, 3 -1,3-glucanase, peroxidase and salicylic acid, in relation to the controls (Figure 3 ).

Table 3. Number of conidia and appressoria formed during the exposure to Sarocladium oryzae filtrates of the BRM 6461 and BRM 6493 isolates.

\begin{tabular}{ccccccc}
\hline & \multicolumn{7}{c}{ Time } \\
\cline { 2 - 7 } Treatment & GT/A & GT/A & GT/A & GT/A & GT/A & GT/A \\
\cline { 2 - 7 } & $0 \mathrm{~h}$ & $1 \mathrm{~h}$ & $3 \mathrm{~h}$ & $6 \mathrm{~h}$ & $12 \mathrm{~h}$ & $20 \mathrm{~h}$ \\
\hline BRM 6461 & $0^{\text {ns }} / 0^{\text {ns } 1}$ & $2.7 \mathrm{a}^{*} / 0^{\text {ns }}$ & $47.3^{\text {ns }} / 0.00^{\text {ns }}$ & $51.0^{\text {ns }} / 0.00^{\text {ns }}$ & $51.3^{\text {ns }} / 0.00^{\text {ns }}$ & $53.7^{\text {ns }} / 0.00 \mathrm{a}$ \\
BRM 6493 & $0 / 0$ & $4.0 \mathrm{a} / 0$ & $48.7 / 0.00$ & $52.3 / 0.00$ & $53.3 / 0.00$ & $56.7 / 2.00 \mathrm{a}$ \\
Control & $0 / 0$ & $32.3 \mathrm{~b} / 0$ & $50.3 / 0.00$ & $52.7 / 0.00$ & $52.7 / 0.00$ & $52.3 / 42.7 \mathrm{~b}$ \\
\hline GT & 0 germy
\end{tabular}

GT = germ tube; $\mathrm{A}=$ appressoria. ${ }^{*}$ Means followed by the same letter do not differ statistically according to the Tukey test $(\mathrm{p} \leq 0.05) .{ }^{\text {ns }}$ non-significant. 


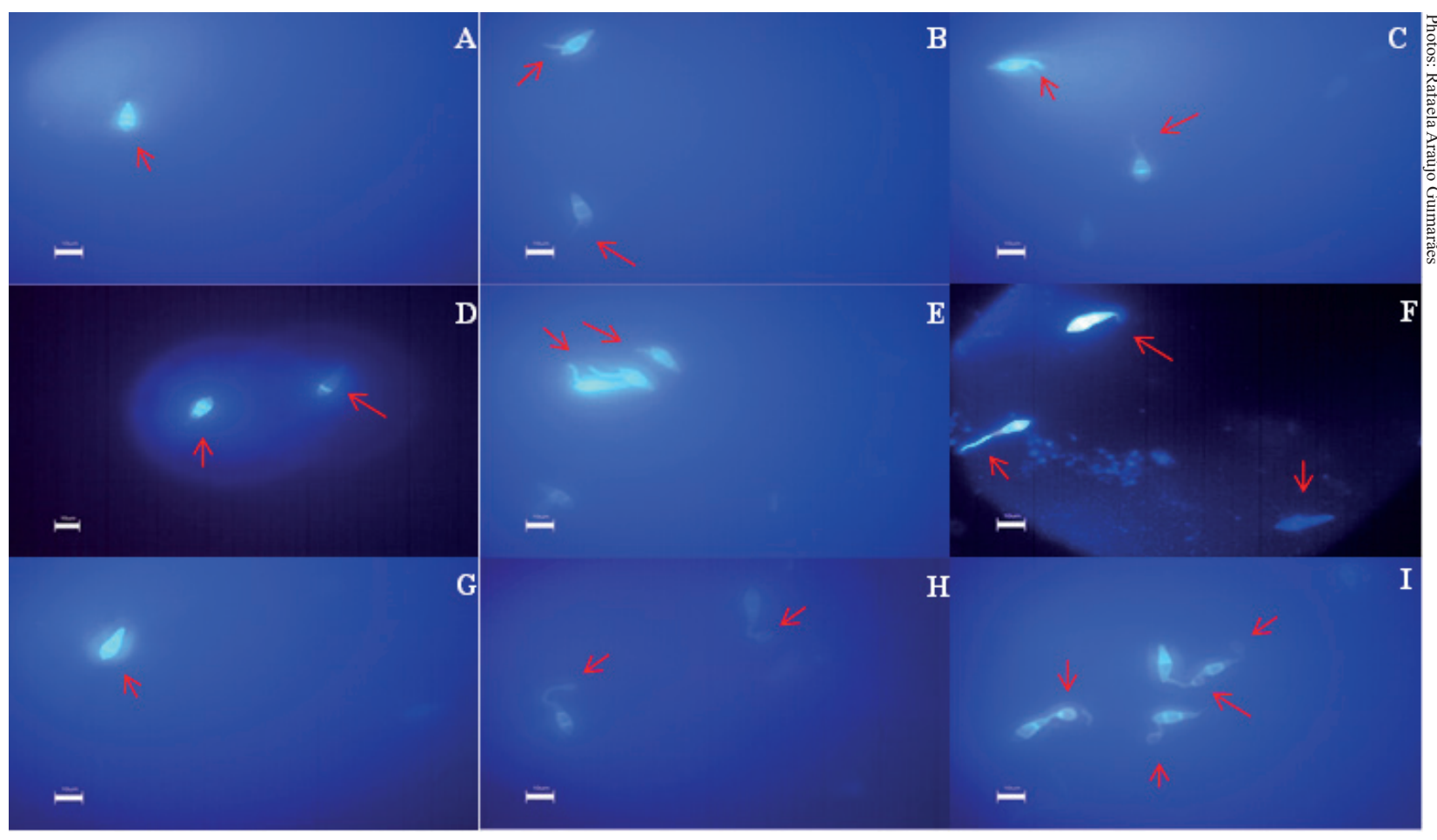

Figure 1. Effect of the Sarocladium oryzae filtrate on the germination and appressorium formation in Magnaporthe oryzae, where: A: 0 h/BRM 6461; B: 12 h/BRM 6461; C: 20 h/BRM 6461; D: 0 h/BRM 6493; E: 12 h/BRM 6493; F: 20 h/BRM 6493; G: 0 h/M. oryzae; H: 12 h/M. oryzae; I: 20 h/M. oryzae. Scale bar $=10 \mu \mathrm{m}$.

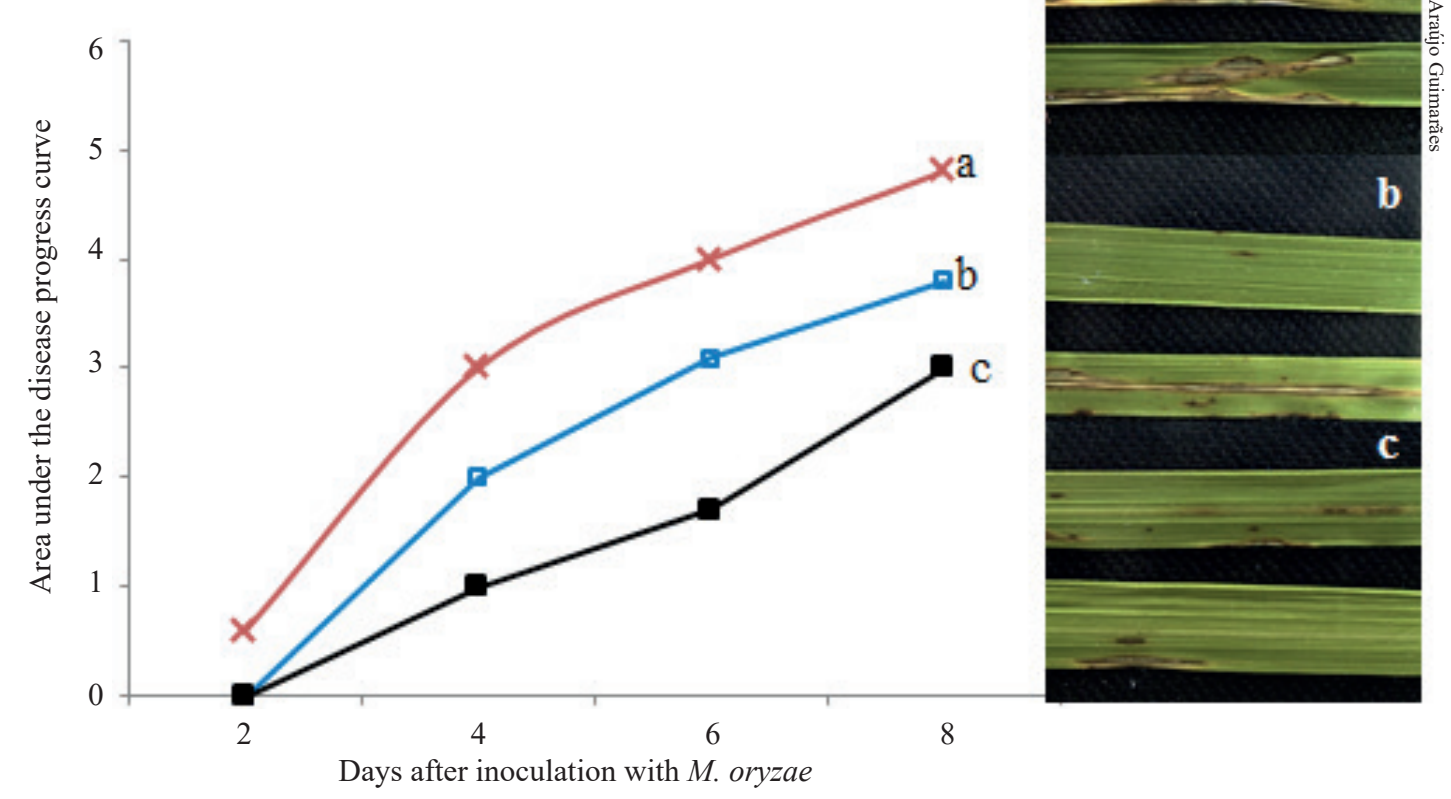

Figure 2. Area under the disease progress curve, where: $a$ is the plant inoculated with Magnaporthe oryzae alone and $b$ and $c$ the plants sprayed with Sarocladium oryzae conidial suspension and BRM 6461 filtrate, at $48 \mathrm{~h}$ before the inoculation with M. oryzae, respectively. * Means differ according to the Tukey test $(\mathrm{p} \leq 0.05)$. 

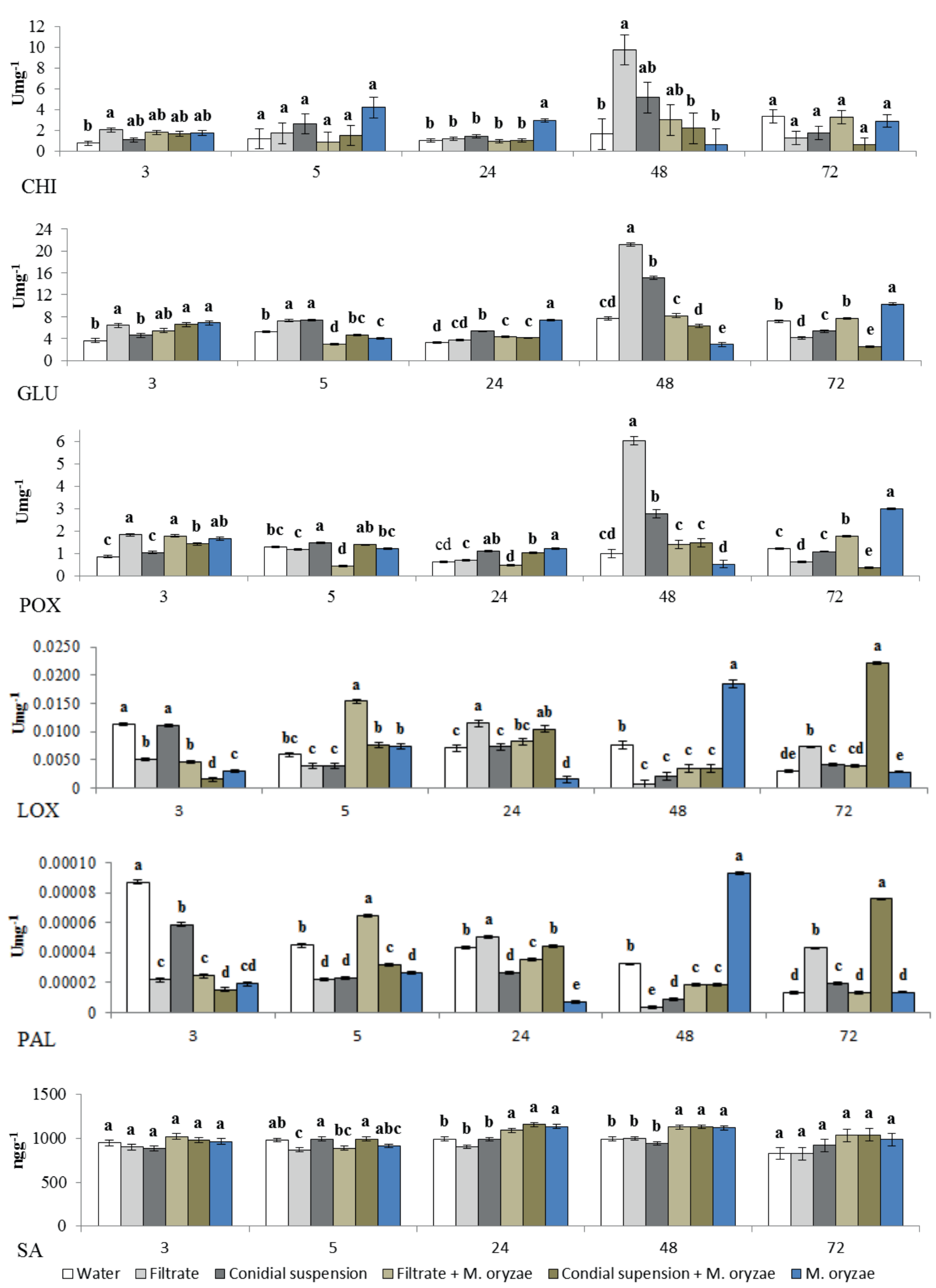

Figure 3. Enzyme activity and salicylic acid content at rice leaf collection times $(3,5,24,48$ and $72 \mathrm{~h}$ after the inoculation with M. oryzae), where: CHI: chitinase; GLU: $\beta$-1,3-glucanase; POX: peroxidase; LOX: lipoxygenase; PAL: phenylalanine ammonia lyase; SA: salicylic acid. * Means followed by the same letter do not differ according to the Tukey test $(\mathrm{p} \leq 0.05)$. 
Defense mechanisms are associated with metabolic changes such as alterations in key enzymes of the primary and secondary metabolism (Araújo \& Menezes 2009), including: chitinase and $\beta$-1,3-glucanase, well known pathogenesis-related proteins (Van Loon et al. 2006); lipoxygenase, which inhibits pathogen growth, inducing the phytoalexin production (Wang 2004); phenylalanine ammonia lyase, which is involved in the phenylpropanoid synthesis (Hyodo et al. 1978), resulting in the synthesis of compounds such as phytoalexins and primary lignin, making the cell walls of plants more pathogen-resistant (Nakazawa et al. 2001); and peroxidase, which acts in the oxidation of phenolic compounds that are toxic to pathogens (Sutic \& Sinclair 1991).

Hydroperoxide lyase is a reaction product of lipoxygenase that produces aldehydes responsible for inhibiting the growth of fungi, insects and protozoa on plant tissue. Hydroperoxide cyclase is also a lipoxygenase reaction product formed by lipid degradation that, after reduction and oxidation, produces jasmonic acid, which regulates growth and is also involved in the development of plant response to lesions and pathogens (Croft et al. 1993). Thus, spraying with cerulenin, a secondary metabolite composed primarily of fatty acids and steroids (Hittalmani et al. 2016), increased lipoxygenase levels and activated the defense of rice plants against M. oryzae, evidenced by the reduced disease severity.

Another enzyme responsible for the reduction in the rice leaf blast severity by $S$. oryzae was phenylalanine ammonia lyase, which produces phenolic compounds with antimicrobial potential, as well as some phytoalexins (Schuster \& Rétey 1995). The phenylalanine ammonia lyase production is regulated during plant growth, but is also induced in cells adjacent to the infection site by different environmental stimuli, such as infection, injury, contamination by heavy metals, light and growth regulators (Rahman \& Punja 2005). According to Baysal et al. (2003) and Macagnan et al. (2008), changes in the activity of key enzymes such as lipoxygenase and phenylalanine ammonia lyase make it possible to monitor induced resistance in plants, when exposed to pathogens.

Some studies have already demonstrated the activation of defense mechanisms in rice plants against blight by antagonists using bacteria and fungi. Sha et al. (2016) reported that Bacillus subtilis can activate these defense mechanisms by acting on the growth hyphae of M. oryzae, consequently reducing the length of the germinative tube, reflecting on the germination of conidia. These morphological changes compromise the $M$. oryzae infection in plants and increase the activity of some enzymes, such as peroxidase. Law et al. (2017) evaluated different species of Streptomyces in a greenhouse and also obtained success, reducing in up to $88.3 \%$ the severity of the disease, a fact linked to the production of bioactive compounds by these strains. Some rhizobacteria, such as the Pseudomonas fluorescens genus, have been described by De Vleesschauwer et al. (2008), promoting the induction of systemic resistance due to the production of siderophores of the pseudobactin type. The same authors concluded that this interaction of $M$. oryzae with rice presents not only one, but multiple resistance pathways. Other studies using fungi as antagonists reported reduction in the rice leaf blast severity, such as those by Chaibub et al. (2016) and Sena et al. (2013), using Cladosporium sp. and Epicoccum sp., respectively. Both antagonists, when applied before the presence of $M$. orzyae, reduced the rice leaf blast severity by more than $70 \%$ and increased levels of defense-related enzymes.

These results should be tested in the field for possible inclusion in integrated disease management, in order to reduce the use of fungicides in the control of rice leaf blast. But it is still necessary a better understanding of the defense mechanisms, as well as the metabolic pathways and the genes involved in the defense system of the rice plant, where $S$. oryzae can act in the protection against $M$. oryzae.

\section{CONCLUSION}

The Sarocladium oryzae BRM 6461 isolate, in filtrate form, composed primarily of the secondary metabolite cerulenin, delays the germination and inhibits the formation of Magnaporthe oryzae appressoria, besides reducing the rice leaf blast severity.

\section{ACKNOWLEDGMENTS}

The authors are grateful to the Embrapa Arroz e Feijão, Universidade Federal de Goiás (UFG), Conselho Nacional de Desenvolvimento Científico e Tecnológico $(\mathrm{CNPq})$ and Fundação de Amparo à Pesquisa do Estado de Goiás (FAPEG), for supporting this project (nº. 012/2012). 


\section{REFERENCES}

ALUNNI, S. et al. Mechanisms of inhibition of phenylalanine ammonia-lyase by phenol inhibitors and phenol/glycine synergistic inhibitors. Archives of Biochemistry and Biophysics, v. 412, n. 2, p. 170-175, 2003.

ARAÚJO, F. F.; MENEZES, D. Indução de resistência a doenças foliares em tomateiro por indutores biótico (Bacillus subtilis) e abiótico (Acibenzolar-S-Metil). Summa Phytopathologica, v. 35, n. 3, p. 169-172, 2009.

ASHIZAWA, T.; ZENBAYASHI, K.; SONODA, R. Effects of preinoculation with an avirulent isolate of Pyricularia grisea on infection and development of leaf blast lesions caused by virulent isolates on near-isogenic lines of Sasanishiki rice. Journal of General Plant Pathology, v. 71, n. 5, p. 345-350, 2005.

AXELROD, B. et al. Lipoxygenase from soybeans. Methods in Enzymology, v. 71, n. 1, p. 441-451, 1981.

BALARDIN, R. S. et al. Resistência de germoplasma de feijão (Phaseolus vulgaris L.) a Fusarium oxysporum $\mathrm{f}$. sp. phaseoli. Fitopalogia Brasileira, v. 17, n. 1, p. 102103, 1990.

BAYSAL, Ö.; SOYLU, E. M.; SOYLU, S. Induction of defence-related enzymes and resistance by the plant activator acibenzolar-S-methyl in tomato seedlings against bacterial canker caused by Clavibacter michiganensis ssp. michiganensis. Plant Pathology, v. 52, n. 6, p. 747-753, 2003.

BILLS, G. F. et al. Conspecificity of the cerulenin and helvolic acid producing 'Cephalosporium caerulens', and the hypocrealean fungus Sarocladium oryzae. Mycological Research, v. 108, n. 11, p. 1291-1300, 2004.

BRADFORD, M. M. A rapid and sensitive method for the quantitation of microgram quantities of protein utilizing the principle of protein-dye binding. Analytical biochemistry, v. 72, n. 1-2, p. 248-254, 1976.

CAMPBELL, C. L.; MADDEN, L. V. Introduction to plant disease epidemiology. New York: John Wiley \& Sons., 1990.

CANTERI, M. G. et al. SASM-Agri: sistema para análise e separação de médias em experimentos agrícolas pelos métodos Scott-Knott, Tukey e Duncan. Revista Brasileira de Agrocomputação, v. 1, n. 2, p. 18-24, 2001.

CHAIBUB, A. A. et al. Defence responses in rice plants in prior and simultaneous applications of Cladosporium sp. during leaf blast suppression. Environmental Science and Pollution Research, v. 23, n. 21, p. 21554-21564, 2016.

CHEN, C. et al. Genome comparison of two Magnaporthe oryzae field isolates reveals genome variations and potential virulence effectors. BMC Genomics, v. 14, n. 1, p. 887-899, 2013.

CÔRTES, M. V. C. B. et al. Potential for using crude extract of Sarocladium oryzae for suppression of rice blast. Tropical Plant Pathology, v. 39, n. 1, p. 28-34, 2014.

CÔRTES, M. V. C. B. et al. Quantificação da atividade enzimática de proteínas relacionadas à patogênese no patossistema Oryza sativa/Magnaporthe grisea. Boletim de Pesquisa e Desenvolvimento, v. 34, n. 1, p. 1-18, 2008.

CROFT, K. P. C.; JUTTNER, F.; SLUSARENKO, A. J. Volatile products of the lipoxygenase pathway evolved from Phaseolus vulgaris (L.) leaves inoculated with Pseudomonas syringae pv. phaseolicola. Plant Physiology, v. 101, n. 1, p. 13-24, 1993.

DE VLEESSCHAUWER, D. et al. Pseudomonas fluorescens WCS374r-induced systemic resistance in rice against Magnaporthe oryzae is based on pseudobactinmediated priming for a salicylic acid-repressible multifaceted defense response. Plant Physiology, v. 148, n. 4, p. 1996-2012, 2008.

DURRANT, W. E.; DONG, X. Systemic acquired resistance. Annual Review of Phytopathology, v. 42, n. 1, p. 185-209, 2004.

EBBOLE, D. J. Magnaporthe as a model for understanding host-pathogen interactions. Annual Review of Phytopathology, v. 45, n. 1, p. 437-456, 2007.

EMPRESA BRASILEIRA DE PESQUISA AGROPECUÁRIA (Embrapa). Sistema brasileiro de classificação de solos. 3. ed. Brasília, DF: Embrapa, 2013.

FILIPPI, M. C. C. et al. Leaf blast (Magnaporthe oryzae) suppression and growth promotion by rhizobacteria on aerobic rice in Brazil. Biological Control, v. 58, n. 2, p. 160-166, 2011.

FILIPPI, M. C. C.; SILVA, G. B.; PRABHU, A. S. Indução de resistência à brusone em folhas de arroz por isolado avirulento de Magnaporthe oryzae. Fitopatologia Brasileira, v. 32, n. 5, p. 387-392, 2007.

FILIPPI, M. C. et al. Induction of resistance to rice leaf blast by avirulent isolates of Magnaporthe oryzae. Revista de Ciências Agrárias, v. 57, n. 4, p. 388-395, 2014.

FILIPPI, M. C.; PRABHU, A. S. Phenotypic virulence analysis of Pyricularia grisea isolates from Brazilian upland rice cultivars. Pesquisa Agropecuária Brasileira, v. 36, n. 1, p. 27-35, 2001.

FISHER, M. C. et al. Emerging fungal threats to animal, plant and ecosystem health. Nature, v. 484, n. 7393, p. 186-194, 2012. 
GNANAMANICKAM, S. S.; MEW, T. W. Interactions between Sarocladium oryzae and stem attacking fungal pathogens of rice. Plant and Soil, v. 138, n. 2, p. 213219, 1991.

HITTALMANI, S. et al. De novo genome assembly and annotation of rice sheath rot fungus Sarocladium oryzae reveals genes involved in helvolic acid and cerulenin biosynthesis pathways. BMC Genomics, v. 17, n. 1, p. 271, 2016.

HYODO, H.; KURODA, H.; YANG, S. F. Induction of phenylalanine ammonia-lyase and increase in phenolics in lettuce leaves in relation to the development of russet spotting caused by ethylene. Plant Physiology, v. 62, n. 1, p. 31-35, 1978.

KEESEY, J. Biochemica information. Boehringer Mannheim Biochemicals, v. 1, n. 1, p. 56-59, 1987.

KLAUBAUF, S. et al. Resolving the polyphyletic nature of Pyricularia (Pyriculariaceae). Studies in Mycology, v. 79, n. 1, p. 85-120, 2014.

LAW, J. W. et al. The potential of Streptomyces as biocontrol agents against the rice blast fungus, Magnaporthe oryzae (Pyricularia oryzae). Frontiers in Microbiology, v. 8, n. 3, p. 1-10, 2017.

LEUNG, H. et al. Genetic analysis of virulence in the rice blast fungus Magnaporthe grisea. Phytopathology, v. 78, n. 9, p. 1227-1233, 1988.

MACAGNAN, D. et al. Atividade de enzimas associadas ao estado de indução em mudas de cacaueiro expostas a dois actinomicetos residentes de filoplano. Summa Phytopathologica, v. 34, n. 1, p. 34-37, 2008.

MANANDHAR, H. K. et al. Resistance to rice blast induced by ferric chloride, di-potassium hydrogen phosphate and salicylic acid. Crop Protection, v. 17, n. 4, p. 323-329, 1998.

MENG, X. et al. Dry flowable formulations of antagonistic Bacillus subtilis strain T429 by spray drying to control rice blast disease. Biological Control, v. 85, n. 1, p. 4651, 2015.

MISHINA, T. E.; ZEIER, J. Pathogen-associated molecular pattern recognition rather than development of tissue necrosis contributes to bacterial induction of systemic acquired resistance in Arabidopsis. The Plant Journal, v. 50, n. 3, p. 500-513, 2007.

NAKAZAWA, A. et al. Expression pattern and gene structure of phenylalanine ammonia-lyase in Pharbitis nil. Journal of Plant Research, v. 114, n. 3, p. 323-328, 2001.

NIE, Y. et al. Evaluation and genetic classification of rice germplasm resources resistant to rice blast. Agricultural Biotechnology, v. 3, n. 2, p. 1-6, 2014.
OHTAKE, M.; YAMAMOTO, H.; UCHIYAMA, T. Influences of metabolic inhibitors and hydrolytic enzymes on the adhesion of appressoria of Pyricularia oryzae to wax-coated cover-glasses. Bioscience, Biotechnology, and Biochemistry, v. 63, n. 6, p. 978-982, 1999.

OLIVEIRA, S. C et al. Resistência cruzada aos fungicidas IQo azoxistrobina e piraclostrobina no patógeno da brusone do trigo Pyricularia oryzae no Brasil. Summa Phytopathologica, v. 41, n. 3, p. 298-304, 2015.

OMURA, S. The Antibiotic cerulenin, a novel tool for biochemistry as an inhibitor of fatty acid synthesis. Bacteriological Reviews of the American Society for Microbiology, v. 40, n. 3, p. 681-697, 1976.

PADMAVATI, M. et al. Differential sensitivity of rice pathogens to growth inhibition by flavonoids. Phytochemistry, v. 46, n. 3, p. 499-502, 1997.

PAN, S. Q.; YE, X. S.; KUĆ, J. Association of $\beta-1$, 3 -glucanase activity and isoform pattern with systemic resistance to blue mould in tobacco induced by stem injection with Peronospora tabacina or leaf inoculation with tobacco mosaic virus. Physiological and Molecular Plant Pathology, v. 39, n. 1, p. 25-39, 1991.

PIETERSE, C. M. J. et al. Networking by small-molecule hormones in plant immunity. Nature Chemical Biology, v. 5, n. 5, p. 308-316, 2009.

PRABHU, A. S. et al. In vitro inhibition of Pyricularia grisea by Sarocladium oryzae, the causal agent of sheath rot disease. Tropical Plant Pathology, v. 32, n. 1, p. S258, 2007.

PRABHU, A. S. et al. An unprecedented outbreak of rice blast on a newly released cultivar BRS Colosso in Brazil. In: GUO-LIANG, W.; VALENT, B. Advances in genetics, genomics and control of rice blast disease. Changsha: Springer, 2009. p. 257-266.

RAHMAN, M.; PUNJA, Z. K. Biochemistry of ginseng root tissues affected by rusty root symptoms. Plant Physiology and Biochemistry, v. 43, n. 12, p. 1103-1114, 2005.

ROMEIRO, R. S. Controle biológico de doenças de plantas: procedimentos. Viçosa: Ed. UFV, 2007.

SAKTHIVEL, N.; AMUDHA, R.; MUTHUKRISHNAN, S. Production of phytotoxic metabolites by Sarocladium oryzae. Mycological Research, v. 106, n. 5, p. 609-614, 2002.

SAKTHIVEL, N.; GNANAMANICKAM, S. S. Isolation of and assay for cerulenin produced by rice sheath-rot pathogen Sarocladium oryzae (SAW) GAMS. Current Science, v. 55, n. 19, p. 988-989, 1986. 
SCHUSTER, B.; RÉTEY, J. The mechanism of action of phenylalanine ammonia-lyase: the role of prosthetic dehydroalanine. Proceedings of the National Academy of Sciences, v. 92, n. 18, p. 8433-8437, 1995.

SENA, A. et al. Increased enzymatic activity in rice leaf blast suppression by crude extract of Epicoccum sp. Tropical Plant Pathology, v. 38, n. 5, p. 387-397, 2013.

SHA, Y.; WANG, Q.; LI, Y. Suppression of Magnaporthe oryzae and interaction between Bacillus subtilis and rice plants in the control of rice blast. SpringerPlus, v. 5, n. 1, p. 1238-1251, 2016.

SHORESH, M.; HARMAN, G. E.; MASTOURI, F. Induced systemic resistance and plant responses to fungal biocontrol agents. Annual Review of Phytopathology, v. 48 , n. 1, p. 21-43, 2010.

SILVA, L. P. S. et al. Inibição in vitro de Pyricularia grisea por Sarocladium oryzae, o agente causal da podridão da bainha em arroz. In: CONGRESSO BRASILEIRO DE FITOPATOLOGIA, 40., 2007, Maringá. Resumos... Maringá: Fitopatologia Brasileira, 2007. p. S258.

SMITH, J. A.; MÉTRAUX, J. P. Pseudomonas syringae pv. syringae induces systemic resistance to Pyricularia oryzae in rice. Physiological and Molecular Plant Pathology, v. 39, n. 6, p. 451-461, 1991.

SUTIC, D. D.; SINCLAIR, J. B. Anatomy and physiology of diseased plants. Boston: CRC Press, 1991.
TSCHEN, J. et al. Isolation and phytotoxic effects of helvolic acid from plant pathogenic fungus Sarocladium oryzae. Botanical Bulletin of Academia Sinica, v. 38, n. 1, p. 251-256, 1997.

TSCHEN, J.; WEN, F. S. Physiological studies on etiology of the sterility of rice plants. Plant Protection Bulletin, v. 22, n. 1, p. 57-62, 1980.

TSUDA, K. et al. Interplay between MAMP-triggered and SA-mediated defense responses. The Plant Journal, v. 53, n. 5, p. $763-775,2008$.

TSUKAMOTO, $\mathrm{H}$. et al. Biological control of rice leaf blast with Exserohilum monoceras, a pathogen of Echinochloa species. Japanese Journal of Phytopathology, v. 65 , n. 5 , p. 543-548, 1999.

VAN LOON, L. C.; BAKKER, P. A. H. M.; PIETERSE, C. M. J. Systemic resistance induced by rhizosphere bacteria. Annual Review of Phytopathology, v. 36, n. 1, p. 453-483, 1998 .

VAN LOON, L. C.; REP, M.; PIETERSE, C. M. J. Significance of inducible defense-related proteins in infected plants. Annual Review of Phytopathology, v. 44, n. 1, p. 135-162, 2006.

WANG, X. Lipid signaling. Current Opinion in Plant Biology, v. 7, n. 3, p. 329-336, 2004.

YALPANI, N. et al. Salicylic acid is a systemic signal and an inducer of pathogenesis-related proteins in virusinfected tobacco. Plant Cell, v. 3, n. 8, p. 809-818, 1991. 